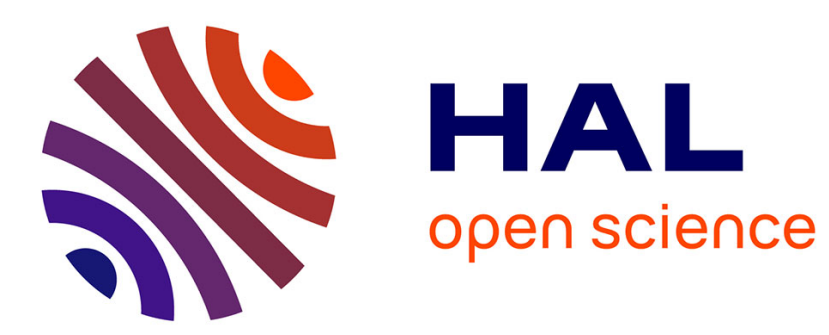

\title{
L14. Immunomodulatory properties of apoptotic cells.
}

Sylvain Perruche, Philippe Saas

\section{To cite this version:}

Sylvain Perruche, Philippe Saas. L14. Immunomodulatory properties of apoptotic cells.. La Presse medicale, 2013, 42 (4 Pt 2), pp.537-43. 10.1016/j.lpm.2013.01.013 . inserm-00804453

\section{HAL Id: inserm-00804453 https://www.hal.inserm.fr/inserm-00804453}

Submitted on 25 Mar 2013

HAL is a multi-disciplinary open access archive for the deposit and dissemination of scientific research documents, whether they are published or not. The documents may come from teaching and research institutions in France or abroad, or from public or private research centers.
L'archive ouverte pluridisciplinaire HAL, est destinée au dépôt et à la diffusion de documents scientifiques de niveau recherche, publiés ou non, émanant des établissements d'enseignement et de recherche français ou étrangers, des laboratoires publics ou privés. 


\section{Immunomodulatory properties of apoptotic cells}

Sylvain Perruche $e^{1,2,3,4}$ and Philippe Saas s, $2,3,4^{2}$

${ }^{1}$ INSERM UMR1098, F25020 Besançon cedex, France

${ }^{2}$ Université de Franche-Comté, SFR FED4234, F25000 Besançon cedex, France

${ }^{3}$ EFS Bourgogne Franche-Comté, F25020 Besançon cedex, France

${ }^{4}$ LabEX LipSTIC, ANR-11-LABX-0021, F25020 Besançon cedex, France

Address for correspondence: Sylvain Perruche, INSERM UMR1098, UFC, EFS Bourgogne

Franche-Comté, 1 boulevard A Fleming, F25020 Besançon Cedex, France. Phone: +33

381615615. Fax: +33 381615800. sylvain.perruche@efs.sante.fr

Keywords:Phagocytes, TGF- $\beta$, tolerance, inflammation 


\section{INTRODUCTION}

Chronic inflammation usually originates from a dysfunction in tolerance processes implicating a variety of soluble factors and immune cells. In homeostatic conditions, an inflammatory event triggering by, for instance, pathogen invasion, necrotic damaged cells or irritants is a natural process initiatedto protect the target tissue, remove the injurious stimulus, and then initiate the healing process. Such a process detects and engages immune cells that are able to restore toleranceconsequently. A defect in that process could lead to a continuous stimulation of immune cells, overpassing tolerogenic mechanisms andthus leading to chronic inflammation. Such a defect can implicate one or many factors and/or effector cells that can sustain inflammatory signals overwhelming inflammation. A way to break the inflammatory process is to reintroduce in the damaging loop factors that will favor the production of anti-inflammatory elements and desensitize immune responsesorchestrated byantigen presenting cells, thusallowing immune cells to take control all over again. One strategy is to use apoptotic cell injection in order to benefit from their direct and indirect immunomodulatory properties to favor tolerance induction. This has been already evaluated in many experimental models and proposedin a fewclinical trials.

\section{APOPTOTIC CELLS}

One of the key elements allowing restoration of homeostasis is apoptotic cell death. First, after doing their job such as elimination of pathogens, reactive $\mathrm{T}$ cells need to graciously disappear mainly through apoptotic cell death. Apoptotic cell death, i.e., apoptosis, is a physiological mechanism that allows the elimination of cells inexcess or unwantedcells preventing an inflammatory process $(1,2)$. The lack of inflammation associated with apoptosis is attributed to the fact that professional phagocytes (mainly macrophages and subpopulations of dendritic cells)-but also neighbor cells- efficiently engulf apoptotic cells and apoptotic residues called 
apoptotic bodies. This prevents the secondary necrosis of apoptotic cells, a pro-inflammatory cell death (3), and so, the release of proteases and other inflammatory mediators as alarmines $(4,5)$ by late apoptotic/necrotic cells $(3,6,7)$. Efficient apoptotic cell removal is governed by multiple signals delivered by apoptotic cells including: "find me" signals responsible for professional phagocyte attraction, the expression of "eat me" signals and the repression of "don't eat me" signals to avoid the elimination of viable cells (Fig. 1) $(8,9)$. Regulation is also provided by "keep out" signals such as lactoferrinthat prevent neutrophil migration(10).

The mechanisms associated with the efficient elimination of cells entering apoptosis are also associated with thoseallowing the preventionof the immune response initiation. These mechanisms are critical and redundant as they should prevent the occurrence of autoimmune diseases $(11,12)$. It is possible to distinguish two types of mechanisms: those directly related to apoptotic cell death and the others dependent on their elimination by phagocytic cells. Thus, phagocytes will shape a new microenvironment through the secretion of soluble factors affecting themselves as well as all the neighboring cells,preventing in concert the appearance of unwanted immune response deleterious to the host.

\section{DIRECT EFFECT OF APOPTOTIC CELLS}

Several studies report that during the process of apoptosis,apoptotic cells secrete immunosuppressive cytokines such as IL-10 and TGF- $\beta(13,14)$. TGF- $\beta$, stored in a latent form in intracellular compartments, is released during apoptosis (13). Cytokine release allows to generate immunosuppressive microenvironment, inhibits the secretion of pro-inflammatory cytokines (TNF- $\alpha$ or IL-1 $\beta$ ) by macrophages $(15,16)$ and neutralize the development of an 
effective immune response. This also prevents the initiation of an immune response targeting antigenspresent on -or expressed by- apoptotic cells, and thus prevents autoimmune responses. Indeed, apoptotic bodies escaping from removal have been reported to cluster clinical relevant auto-antigens at their surface(17). These auto-antigens are exposed at cell surface or translocated

from internal compartments to cell membrane during early stages of apoptosis(18, 19). Apoptotic cells arealso able to clear or neutralize inflammatory chemokines, such as CCL3 and CCL5 via CCR5 expression, thus preventing the migration of other leukocytes (20). All these immunosuppressive effects are time-limited until the cell dislocation occurs through secondary necrosis and so, other mechanisms need to take place to prevent chronic inflammation.

\section{INDIRECT EFFECT OF APOPTOTIC CELLS}

Apoptotic cells also allow the development of an immunomodulatory environment indirectly through phagocytic cells. Indeed, professional phagocytic cells such as macrophages can release or express immunosuppressive molecules (IL-10, TGF- $\beta$, prostaglandin E2 or PGE-2, Fas ligand) in the clearance of apoptotic cells (21-23). Thus, apoptotic cells have immunosuppressive properties in vitro notably through the secretion of IL-10 which inducesin vivo immune deviation to type 2cytokine secretion $(14,21,22)$. The production of TGF- $\beta 1$ is observed during phagocytosis by macrophages or immature dendritic cells(15, 23). In addition, it has been shown that phagocytosis of apoptotic cells induce a down-regulation of IL-12 secretion as well as TNF by macrophages and could also block the synthesis of pro-inflammatory cytokines by interfering with NF-kappaB(24-26). The elimination of apoptotic neutrophils inhibits the synthesis of cytokines called "Th17", such as IL-23 and IL-17 by phagocytic cells (27). Altogether, this suggests that pro-inflammatory Th1 and Th17 responses are prevented by professional phagocytes participating in apoptotic cell removal. 


\section{ROLE OF MACROPHAGES AND DENDRITIC CELLS}

Macrophages appear to be the main phagocytic cells which remove most effectively apoptotic cells $(15,28,29)$. Indeed, they express a large number of membrane receptors involved in this elimination (Fig.1). The stimulation of these receptors favors induction of animmunomodulatoryphenotype of the phagocytes. Many immunomodulatory mechanisms have been reported. They are represented mainly by the release of soluble factors such as cytokines IL-10 or TGF- $\beta$. Macrophage functions will be limited after removal of apoptotic cells. In addition, some subpopulations of dendritic cells have been involved also in the capture of apoptotic cells $(23,30-34)$. One study conducted on rats showed that a subpopulation of circulating dendritic cells would be responsible for capturing continuously apoptotic cells and bodies from intestinal epithelial cells removed every day after desquamation. Then, dendritic cells migrate to the mesenteric lymph nodeswhere they inactivate the naïve autoreactiveT cells $(30,32,35)$. Other experimental studies also suggest that the capture of apoptotic cells by dendritic cell subsets leads to tolerance $(23,31,33,34)$. In addition, an in vitro study showeddendritic cells that have captured apoptotic cells did not respond to lipopolysaccharide (36).This is also true for macrophages (26). Thus, professional phagocytes that encountered apoptotic cells become refractory to Danger signal triggering.

\section{A consequence of the interaction ofapoptotic bodies and phagocytic cells: induction of regulatory $\mathbf{T}$ cells}

The consequences of apoptotic cell-phagocyte interactions influence the differentiation of naïve $\mathrm{CD} 4^{+} \mathrm{T}$ cells. Although contact with apoptotic cells blocks the ability of maturation and cytokine production of conventional dendritic cells, their migration capabilities are not affected or at least 
redefined. So, dendritic cells can acquire the expression of CCR7 and migrate in response to gradients of CCL19 and CCL21 to the lymph nodes closest to the site where the cells died (37, 38). In the lymph nodes, such dendritic cells can interact with naive $\mathrm{CD}^{+} \mathrm{T}$ cells and deliver a "tolerogenic" signal to the $\mathrm{T}$ cellfavoring $\mathrm{T}$ cell commitment to a regulatory phenotype, such as induced Foxp $3^{+}$regulatory T cells (Treg) or IL- $10^{+}$Tr1 cells $(23,39-41)$. Whether natural Treg commitment in the thymus also respects such mechanism is still uncertain. However, several dendritic cell subsets are able to migrate from the periphery to the thymus to transport peripheral antigens(42). This may occur via the capture of auto-antigens from apoptotic cells. A main feature of Treg generated by dendritic cells is their ability to increase production of IL-10 (43, 44). It was also suggested that plasmacytoid dendritic cells are the dendritic cell subtype favoring Tr1 commitment(45). In addition, plasmacytoid dendritic cells can also promote the differentiation of inducible Foxp $3^{+}$Treg(46-48).Immature plasmacytoid dendritic cells transport antigens from the periphery to the thymusvia the expression of CCR9, $\alpha 4$-integrin and functional binding sites for P-selectin(49), and human thymicplasmacytoid dendritic cells favor natural Treg generation $(50,51)$.

Apoptotic cells are endowed with immunomodulatory properties by targeting innate and adaptive immunity at different levels like at the microenvironment level, the polarization of antigen presenting cells, T and B cells. Generation of regulatory B cells (Breg) has also been reported(52). The immunomodulatory microenvironment created through apoptotic cell elimination suggests that apoptotic cell injection might be a powerful tool to control inflammation and restore tolerance in vivo. Thus, our group and others have demonstrated in various experimental models that indeed apoptotic cell injection can control inflammation allowing the restoration of homeostasis and in some settings, tolerance induction (Table 1). 
These accumulated data also favored the initiation of clinical trials, the first one demonstrating the safety of the approach and the second one the efficacy of the approach.

\section{CONCLUSION:TRANSLATIONTO ANTI-NEUTROPHIL CYTOPLASMIC AUTO-ANTIBODY(ANCA)- ASSOCIATED VASCULITIS}

Neutrophil apoptosis may play a role in the pathogenesis of anti-neutrophil cytoplasmic autoantibody (ANCA)-associated systemic vasculitis(53). Several tracks have been proposed to explain its role in the pathophysiological process of ANCA-associated vasculitis. Apoptotic neutrophils can be considered as a Danger signal since they contain a lot of proteases, including serine proteases and elastase(54). However, repeated infusion of apoptotic neutrophils in brown Norway rats has been shown to induce ANCA, but did not lead to systemic vasculitis(55). This suggests that apoptotic neutrophils by themselves are not sufficient to trigger the complete clinical features of ANCA-associated vasculitis. Recent works by Witko-Sarsat and colleagues $(56,57)$ suggest that proteinase- 3 , the target of ANCA in granulomatosis with polyangiitis, delays apoptotic neutrophil removal when expresses at the cell membrane and leads to enhanced secretion of pro-inflammatory cytokines, including: TNF, IL-8 and MIP-1 $\beta$.So, restoring efficient apoptotic neutrophil uptake can be considered as a potential therapeutic approach to treat ANCA-associated vasculitis. 
Table 1.Therapeutic applications of apoptotic cell administration

\begin{tabular}{|c|c|}
\hline & References \\
\hline \multicolumn{2}{|l|}{$\begin{array}{l}\text { Chronic inflammatory autoimmune } \\
\text { diseases }\end{array}$} \\
\hline Diabetes & Xia, 2007 (41); Mougel, 2012 (58) \\
\hline $\begin{array}{l}\text { Experimental Autoimmune } \\
\text { Encephalomyelitis }\end{array}$ & Miyake, 2007 (28); Qiu, 2009 (59) \\
\hline Arthritis & $\begin{array}{l}\text { Gray, } 2007 \text { (52); Perruche, } 2009 \text { (26); } \\
\text { Notley, } 2011 \text { (60) }\end{array}$ \\
\hline \multicolumn{2}{|l|}{ Acute inflammatory diseases } \\
\hline Sepsis & Huynh, 2002 (61); Ren, 2008 (62) \\
\hline Fulminant hepatitis & Zhang, 2011 (63) \\
\hline Contact hypersensitivity & Griffith, 2007 (64) \\
\hline \multicolumn{2}{|l|}{ Transplantation } \\
\hline \multicolumn{2}{|l|}{ Cardiac allograft } \\
\hline Acute rejection & Sun, 2004 (65); Wang, 2006 (66) \\
\hline Chronic rejection & Wang, 2009 (67) \\
\hline Islets allograft & Mougel, 2012(68) \\
\hline \multicolumn{2}{|l|}{ Hematopoietic cell transplantation } \\
\hline Hematopoietic engraftment & $\begin{array}{l}\text { Bittencourt, } 2001 \text { (69); Kleinclauss, } 2006 \\
\text { (39); Perruche, } 2004 \text { (70); Bonnefoy, } 2011 \\
\text { (48) }\end{array}$ \\
\hline Graft-versus-host disease & Kleinclauss, 2006 (39) \\
\hline Allo-antibodies after graft rejection & Perruche, $2004(70)$ \\
\hline Acute myocardial infarction & $\begin{array}{l}\text { Ankersmith, } 2009 \text { (71); Lichtenauer, } 2011 \\
\text { (72) }\end{array}$ \\
\hline
\end{tabular}

Adapted from (73) 


\section{References}

1. Cohen JJ, Duke RC, Fadok VA, Sellins KS. Apoptosis and programmed cell death in immunity. Annu Rev Immunol. 1992;10:267-93.

2. Raff MC. Social controls on cell survival and cell death. Nature. 1992;356(6368):397400.

3. Matzinger P. The danger model: a renewed sense of self. Science. 2002;296(5566):301-5.

4. Lotze MT, Zeh HJ, Rubartelli A, Sparvero LJ, Amoscato AA, Washburn NR, et al. The grateful dead: damage-associated molecular pattern molecules and reduction/oxidation regulate immunity. Immunol Rev. 2007;220:60-81.

5. Kono H, Rock KL. How dying cells alert the immune system to danger. Nat Rev Immunol. 2008;8(4):279-89.

6. Savill J. Apoptosis. Phagocytic docking without shocking. Nature. 1998;392(6675):442-

3.

7. Savill J, Fadok V, Henson P, Haslett C. Phagocyte recognition of cells undergoing apoptosis. Immunol Today. 1993;14(3):131-6.

8. Ravichandran KS. Beginnings of a good apoptotic meal: the find-me and eat-me signaling pathways. Immunity. 2011;35(4):445-55. Epub 2011/11/01.

9. Ravichandran KS. Find-me and eat-me signals in apoptotic cell clearance: progress and conundrums. J Exp Med. 2010;207(9):1807-17. Epub 2010/09/02.

10. Bournazou I, Pound JD, Duffin R, Bournazos S, Melville LA, Brown SB, et al. Apoptotic human cells inhibit migration of granulocytes via release of lactoferrin. J Clin Invest. 2009;119(1):20-32.

11. Morelli AE, Larregina AT. Apoptotic cell-based therapies against transplant rejection: role of recipient's dendritic cells. Apoptosis. 2010;15(9):1083-97.

12. Griffith TS, Ferguson TA. Cell death in the maintenance and abrogation of tolerance: the five Ws of dying cells. Immunity. 2011;35(4):456-66. Epub 2011/11/01.

13. Chen W, Frank ME, Jin W, Wahl SM. TGF-beta released by apoptotic T cells contributes to an immunosuppressive milieu. Immunity. 2001;14(6):715-25.

14. Gao Y, Herndon JM, Zhang H, Griffith TS, Ferguson TA. Antiinflammatory effects of CD95 ligand (FasL)-induced apoptosis. J Exp Med. 1998;188(5):887-96.

15. Fadok VA, Bratton DL, Konowal A, Freed PW, Westcott JY, Henson PM. Macrophages that have ingested apoptotic cells in vitro inhibit proinflammatory cytokine production through autocrine/paracrine mechanisms involving TGF-beta, PGE2, and PAF. J Clin Invest. 1998;101(4):890-8.

16. McDonald PP, Fadok VA, Bratton D, Henson PM. Transcriptional and translational regulation of inflammatory mediator production by endogenous TGF-beta in macrophages that have ingested apoptotic cells. J Immunol. 1999;163(11):6164-72.

17. Casciola-Rosen LA, Anhalt G, Rosen A. Autoantigens targeted in systemic lupus erythematosus are clustered in two populations of surface structures on apoptotic keratinocytes. J Exp Med. 1994;179(4):1317-30.

18. Franz S, Herrmann K, Furnrohr BG, Sheriff A, Frey B, Gaipl US, et al. After shrinkage apoptotic cells expose internal membrane-derived epitopes on their plasma membranes. Cell Death Differ. 2007;14(4):733-42. Epub 2006/12/16.

19. Schiller M, Bekeredjian-Ding I, Heyder P, Blank N, Ho AD, Lorenz HM. Autoantigens are translocated into small apoptotic bodies during early stages of apoptosis. Cell Death Differ. 2008;15(1):183-91. Epub 2007/10/13. 
20. Ariel A, Fredman G, Sun YP, Kantarci A, Van Dyke TE, Luster AD, et al. Apoptotic neutrophils and $\mathrm{T}$ cells sequester chemokines during immune response resolution through modulation of CCR5 expression. Nat Immunol. 2006;7(11):1209-16.

21. Albert ML. Death-defying immunity: do apoptotic cells influence antigen processing and presentation? Nat Rev Immunol. 2004;4(3):223-31.

22. Voll RE, Herrmann M, Roth EA, Stach C, Kalden JR, Girkontaite I. Immunosuppressive effects of apoptotic cells. Nature. 1997;390(6658):350-1.

23. Perruche S, Zhang P, Liu Y, Saas P, Bluestone JA, Chen W. CD3-specific antibodyinduced immune tolerance involves transforming growth factor-beta from phagocytes digesting apoptotic T cells. Nat Med. 2008;14(5):528-35. Epub 2008/04/29.

24. Kim S, Elkon KB, Ma X. Transcriptional suppression of interleukin-12 gene expression following phagocytosis of apoptotic cells. Immunity. 2004;21(5):643-53.

25. Sen P, Wallet MA, Yi Z, Huang Y, Henderson M, Mathews CE, et al. Apoptotic cells induce Mer tyrosine kinase-dependent blockade of NF-kappaB activation in dendritic cells. Blood. 2007;109(2):653-60.

26. Perruche S, Saas P, Chen W. Apoptotic cell-mediated suppression of streptococcal cell wall-induced arthritis is associated with alteration of macrophage function and local regulatory T-cell increase: a potential cell-based therapy? Arthritis Res Ther. 2009;11(4):R104. Epub 2009/07/03.

27. Stark MA, Huo Y, Burcin TL, Morris MA, Olson TS, Ley K. Phagocytosis of apoptotic neutrophils regulates granulopoiesis via IL-23 and IL-17. Immunity. 2005;22(3):285-94.

28. Miyake Y, Asano K, Kaise H, Uemura M, Nakayama M, Tanaka M. Critical role of macrophages in the marginal zone in the suppression of immune responses to apoptotic cellassociated antigens. J Clin Invest. 2007;117(8):2268-78.

29. Wermeling F, Chen Y, Pikkarainen T, Scheynius A, Winqvist O, Izui S, et al. Class A scavenger receptors regulate tolerance against apoptotic cells, and autoantibodies against these receptors are predictive of systemic lupus. J Exp Med. 2007;204(10):2259-65.

30. Huang FP, Platt N, Wykes M, Major JR, Powell TJ, Jenkins CD, et al. A discrete subpopulation of dendritic cells transports apoptotic intestinal epithelial cells to $\mathrm{T}$ cell areas of mesenteric lymph nodes. J Exp Med. 2000;191(3):435-44.

31. Iyoda T, Shimoyama S, Liu K, Omatsu Y, Akiyama Y, Maeda Y, et al. The CD8+ dendritic cell subset selectively endocytoses dying cells in culture and in vivo. J Exp Med. 2002;195(10):1289-302.

32. Krispin A, Bledi Y, Atallah M, Trahtemberg U, Verbovetski I, Nahari E, et al. Apoptotic cell thrombospondin-1 and heparin-binding domain lead to dendritic-cell phagocytic and tolerizing states. Blood. 2006;108(10):3580-9.

33. Liu K, Iyoda T, Saternus M, Kimura Y, Inaba K, Steinman RM. Immune tolerance after delivery of dying cells to dendritic cells in situ. J Exp Med. 2002;196(8):1091-7.

34. Morelli AE, Larregina AT, Shufesky WJ, Zahorchak AF, Logar AJ, Papworth GD, et al. Internalization of circulating apoptotic cells by splenic marginal zone dendritic cells: dependence on complement receptors and effect on cytokine production. Blood. 2003;101(2):611-20.

35. Pettersson A, Wu XC, Ciumas C, Lian H, Chirsky V, Huang YM, et al. CD8alpha dendritic cells and immune protection from experimental allergic encephalomyelitis. Clin Exp Immunol. 2004;137(3):486-95. 
36. Stuart LM, Lucas M, Simpson C, Lamb J, Savill J, Lacy-Hulbert A. Inhibitory effects of apoptotic cell ingestion upon endotoxin-driven myeloid dendritic cell maturation. J Immunol. 2002;168(4):1627-35.

37. Ip WK, Lau YL. Distinct maturation of, but not migration between, human monocytederived dendritic cells upon ingestion of apoptotic cells of early or late phases. J Immunol. 2004;173(1):189-96.

38. Verbovetski I, Bychkov H, Trahtemberg U, Shapira I, Hareuveni M, Ben-Tal O, et al. Opsonization of apoptotic cells by autologous $\mathrm{iC} 3 \mathrm{~b}$ facilitates clearance by immature dendritic cells, down-regulates DR and CD86, and up-regulates CC chemokine receptor 7. J Exp Med. 2002;196(12):1553-61.

39. Kleinclauss F, Perruche S, Masson E, de Carvalho Bittencourt M, Biichle S, RemyMartin JP, et al. Intravenous apoptotic spleen cell infusion induces a TGF-beta-dependent regulatory T-cell expansion. Cell Death Differ. 2006;13(1):41-52. Epub 2005/06/18.

40. Torchinsky MB, Garaude J, Martin AP, Blander JM. Innate immune recognition of infected apoptotic cells directs T(H)17 cell differentiation. Nature. 2009;458(7234):78-82.

41. Xia CQ, Peng R, Qiu Y, Annamalai M, Gordon D, Clare-Salzler MJ. Transfusion of apoptotic beta-cells induces immune tolerance to beta-cell antigens and prevents type 1 diabetes in NOD mice. Diabetes. 2007;56(8):2116-23.

42. Li J, Park J, Foss D, Goldschneider I. Thymus-homing peripheral dendritic cells constitute two of the three major subsets of dendritic cells in the steady-state thymus. J Exp Med. 2009;206(3):607-22.

43. Kavousanaki M, Makrigiannakis A, Boumpas D, Verginis P. Novel role of plasmacytoid dendritic cells in humans: induction of interleukin-10-producing Treg cells by plasmacytoid dendritic cells in patients with rheumatoid arthritis responding to therapy. Arthritis Rheum. 2010;62(1):53-63.

44. Matta BM, Castellaneta A, Thomson AW. Tolerogenic plasmacytoid DC. Eur J Immunol. 2010;40(10):2667-76. Epub 2010/09/08.

45. Wakkach A, Fournier N, Brun V, Breittmayer JP, Cottrez F, Groux H. Characterization of dendritic cells that induce tolerance and $\mathrm{T}$ regulatory 1 cell differentiation in vivo. Immunity. 2003;18(5):605-17.

46. Ochando JC, Homma C, Yang Y, Hidalgo A, Garin A, Tacke F, et al. Alloantigenpresenting plasmacytoid dendritic cells mediate tolerance to vascularized grafts. Nat Immunol. 2006;7(6):652-62.

47. Sharma MD, Hou DY, Liu Y, Koni PA, Metz R, Chandler P, et al. Indoleamine 2,3dioxygenase controls conversion of Foxp3+ Tregs to TH17-like cells in tumor-draining lymph nodes. Blood. 2009;113(24):6102-11.

48. Bonnefoy F, Perruche S, Couturier M, Sedrati A, Sun Y, Tiberghien P, et al. Plasmacytoid dendritic cells play a major role in apoptotic leukocyte-induced immune modulation. J Immunol. 2011;186(10):5696-705. Epub 2011/04/05.

49. Hadeiba H, Lahl K, Edalati A, Oderup C, Habtezion A, Pachynski R, et al. Plasmacytoid dendritic cells transport peripheral antigens to the thymus to promote central tolerance. Immunity. 2012;36(3):438-50. Epub 2012/03/27.

50. Martin-Gayo E, Sierra-Filardi E, Corbi AL, Toribio ML. Plasmacytoid dendritic cells resident in human thymus drive natural Treg cell development. Blood. 2010;115(26):5366-75. 
51. Hanabuchi S, Ito T, Park WR, Watanabe N, Shaw JL, Roman E, et al. Thymic stromal lymphopoietin-activated plasmacytoid dendritic cells induce the generation of FOXP3+ regulatory T cells in human thymus. J Immunol. 2010;184(6):2999-3007. Epub 2010/02/23. 52. Gray M, Miles K, Salter D, Gray D, Savill J. Apoptotic cells protect mice from autoimmune inflammation by the induction of regulatory B cells. Proc Natl Acad Sci U S A. 2007;104(35):14080-5.

53. Kallenberg CG. Dying neutrophils in ANCA-associated vasculitis: good or bad guys? Kidney international. 2002;61(2):758-9. Epub 2002/02/19.

54. Fadok VA, Bratton DL, Guthrie L, Henson PM. Differential effects of apoptotic versus lysed cells on macrophage production of cytokines: role of proteases. J Immunol. 2001;166(11):6847-54. Epub 2001/05/22.

55. Patry YC, Trewick DC, Gregoire M, Audrain MA, Moreau AM, Muller JY, et al. Rats injected with syngenic rat apoptotic neutrophils develop antineutrophil cytoplasmic antibodies. J Am Soc Nephrol. 2001;12(8):1764-8. Epub 2001/07/20.

56. Kantari C, Millet A, Gabillet J, Hajjar E, Broemstrup T, Pluta P, et al. Molecular analysis of the membrane insertion domain of proteinase 3, the Wegener's autoantigen, in RBL cells: implication for its pathogenic activity. J Leukoc Biol. 2011;90(5):941-50. Epub 2011/08/09. 57. Gabillet J, Millet A, Pederzoli-Ribeil M, Tacnet-Delorme P, Guillevin L, Mouthon L, et al. Proteinase 3 , the autoantigen in granulomatosis with polyangiitis, associates with calreticulin on apoptotic neutrophils, impairs macrophage phagocytosis, and promotes inflammation. $\mathbf{J}$ Immunol. 2012;189(5):2574-83. Epub 2012/07/31.

58. Mougel F, Bonnefoy F, Kury-Paulin S, Borot S, Perruche S, Kantelip B, et al. Intravenous infusion of donor apoptotic leukocytes before transplantation delays allogeneic islet graft rejection through regulatory T cells. Diabetes \& metabolism. 2012. Epub 2012/11/28. 59. Qiu CH, Miyake Y, Kaise H, Kitamura H, Ohara O, Tanaka M. Novel subset of CD8 $\{$ alpha $\}+$ dendritic cells localized in the marginal zone is responsible for tolerance to cellassociated antigens. J Immunol. 2009;182(7):4127-36.

60. Notley CA, Brown MA, Wright GP, Ehrenstein MR. Natural IgM is required for suppression of inflammatory arthritis by apoptotic cells. J Immunol. 2011;186(8):4967-72.

61. Huynh ML, Fadok VA, Henson PM. Phosphatidylserine-dependent ingestion of apoptotic cells promotes TGF-beta1 secretion and the resolution of inflammation. J Clin Invest. 2002;109(1):41-50.

62. Ren Y, Xie Y, Jiang G, Fan J, Yeung J, Li W, et al. Apoptotic cells protect mice against lipopolysaccharide-induced shock. J Immunol. 2008;180(7):4978-85.

63. Zhang M, Xu S, Han Y, Cao X. Apoptotic cells attenuate fulminant hepatitis by priming Kupffer cells to produce interleukin-10 through membrane-bound TGF-beta. Hepatology. 2011;53(1):306-16.

64. Griffith TS, Kazama H, VanOosten RL, Earle JK, Jr., Herndon JM, Green DR, et al. Apoptotic cells induce tolerance by generating helpless CD8+ T cells that produce TRAIL. J Immunol. 2007;178(5):2679-87. Epub 2007/02/22.

65. Sun E, Gao Y, Chen J, Roberts AI, Wang X, Chen Z, et al. Allograft tolerance induced by donor apoptotic lymphocytes requires phagocytosis in the recipient. Cell Death Differ. 2004;11(12):1258-64.

66. Wang Z, Larregina AT, Shufesky WJ, Perone MJ, Montecalvo A, Zahorchak AF, et al. Use of the inhibitory effect of apoptotic cells on dendritic cells for graft survival via T-cell deletion and regulatory T cells. Am J Transplant. 2006;6(6):1297-311. 
67. Wang Z, Shufesky WJ, Montecalvo A, Divito SJ, Larregina AT, Morelli AE. In situtargeting of dendritic cells with donor-derived apoptotic cells restrains indirect allorecognition and ameliorates allograft vasculopathy. PLoS One. 2009;4(3):e4940.

68. Mougel F, Bonnefoy F, Kury-Paulin S, Borot S, Perruche S, Kantelip B, et al.

Intravenous infusion of donor apoptotic leukocytes before transplantation delays allogeneic islet graft rejection through regulatory T cells. Diabetes \& metabolism. 2012;38(6):531-7. Epub 2012/11/28.

69. Bittencourt MC, Perruche S, Contassot E, Fresnay S, Baron MH, Angonin R, et al. Intravenous injection of apoptotic leukocytes enhances bone marrow engraftment across major histocompatibility barriers. Blood. 2001;98(1):224-30. Epub 2001/06/22.

70. Perruche S, Kleinclauss F, Bittencourt Mde C, Paris D, Tiberghien P, Saas P. Intravenous infusion of apoptotic cells simultaneously with allogeneic hematopoietic grafts alters anti-donor humoral immune responses. Am J Transplant. 2004;4(8):1361-5. Epub 2004/07/23.

71. Ankersmit HJ, Hoetzenecker K, Dietl W, Soleiman A, Horvat R, Wolfsberger M, et al. Irradiated cultured apoptotic peripheral blood mononuclear cells regenerate infarcted myocardium. Eur J Clin Invest. 2009;39(6):445-56.

72. Lichtenauer M, Mildner M, Baumgartner A, Hasun M, Werba G, Beer L, et al. Intravenous and intramyocardial injection of apoptotic white blood cell suspensions prevents ventricular remodelling by increasing elastin expression in cardiac scar tissue after myocardial infarction. Basic Res Cardiol. 2011;106(4):645-55.

73. Saas P, Gaugler B, Perruche S. Intravenous apoptotic cell infusion as a cell-based therapy toward improving hematopoietic cell transplantation outcome. Ann N Y Acad Sci.

2010;1209:118-26. Epub 2010/10/21.

74. Saas P, Bonnefoy F, Kleinclauss F, Sun Y, Tiberghien P, Gaugler B, et al. [Towards the use of intravenous apoptotic leukocyte infusion as a cell-based therapy approach?]. Transfus Clin Biol. 2008;15(3):98-108. Epub 2008/06/06. Vers l'utilisation therapeutique de l'administration intraveineuse de leucocytes apoptotiques du donneur en therapie cellulaire ?

75. Gregory CD, Rossi AG, Bournazou I, Zhuang L, Willems JJ. Leukocyte migratory responses to apoptosis: the attraction and the distraction. Cell adhesion \& migration. 2011;5(4):293-7. Epub 2011/06/28.

76. He M, Kubo H, Morimoto K, Fujino N, Suzuki T, Takahasi T, et al. Receptor for advanced glycation end products binds to phosphatidylserine and assists in the clearance of apoptotic cells. EMBO reports. 2011;12(4):358-64. Epub 2011/03/15.

77. Friggeri A, Banerjee S, Biswas S, de Freitas A, Liu G, Bierhaus A, et al. Participation of the receptor for advanced glycation end products in efferocytosis. J Immunol.

2011;186(11):6191-8. Epub 2011/04/20. 
Figure 1.Different signals involved in apoptotic cell removal. Different signals orchestrate apoptotic cell removal by neighbor cells or professional phagocytes such as macrophages. This includes: 1) the loss of "don't eat me" signals; 2) the secretion of "find me" signals that can be counterbalanced by "keep out" signals $(74,75)$; 3) the acquisition of "eat me"signals.Adapted from Ref.and updated with the following reviews $(8,9)$ and original publications $(76,77)$. Abbreviations used:BAI-1, Brain Angiogenesis Inhibitor-1; CRP, C reactive protein; CRT, calreticulin; Gas6, Growth Arrest 6; MBP, Mannose Binding Protein; MFG-E8, lactadherin; PS, phosphatidylserines; PSR, phosphatidylserine receptors; PR3, proteinase-3; RAGE, receptor for advanced glycation end products; SRA, Scavenger Receptor A; TSP1, thrombospondin-1. 